\title{
Baják Imre
}

Eszterházy Károly Egyetem/Budapesti Gazdasági Egyetem, Budapest, Magyarország bajak.imre@uni-eszterhazy.hu

\section{Baják Szabolcs}

Budapesti Gazdasági Egyetem, Budapest, Magyarország

bajak.szabolcs@uni-bge.hu

\section{Gubán Ákos}

Budapesti Gazdasági Egyetem, Budapest, Magyarország guban.akos@uni-bge.hu

\section{AZ INFORMÁCIÓS RENDSZEREK TERVEZÉSÉNEK ELMÉLETE ÉS EGY PÉLDA GYAKORLATI MEGVALÓSÍTÁSÁRA A KÖZIGAZGATÁSBAN}

\section{Bevezetés}

A rendszer egymással kölcsönhatásban álló elemek együttese, amely együttmüködés célja egy előre meghatározott cél megvalósítása. A rendszerek egyszerúek és összetettek egyaránt lehetnek. Egyszerüek, ha további alrendszerekre már nem bonthatók, és összetettek, ha további, elkülöníthető alrendszerekre bonthatók.

$\mathrm{Az}$ információs rendszerek általában adatgyüjtési, feldolgozási, tárolási, információelőállítási célt szolgálnak. (Szenteleki - Rózsa, 2007). Raffai (2003) meghatározása szerint az információs rendszer célja és feladata a valós világ objektumainak, azok állapotának, viselkedésének és folyamatainak a jellemzése, (információk) adatok megbízható, pontos tárolása, ellenőrzése, rendszerezése, átalakítása, továbbítása, a szervezet célja szerinti feldolgozása, új (információk) adatok generálása és igény szerinti megjelenítése (Raffai, 2003 idézi Szenteleki - Rózsa, 2007). Az információs rendszerek e meghatározás alapján általában összetett rendszerek.

Az információs rendszerek jelenléte a közszolgálatban is egyre inkább megszokottá, sőt kívánatossá válik. Budai meghatározása szerint az „e-közigazgatás a közszféra kapcsolatrendszerének tudás alapú átalakítását és racionalizált, szolgáltató jellegü újraszervezését jelenti, az infokommunikációs technológiai alkalmazások közmüszerü használata révén" (Budai, 2009, p. 20).

Ahogy a 2014-2020 időszakra vonatkozó Közigazgatás- és Közszolgáltatás-fejlesztési Stratégia fogalmaz:

„A közigazgatás folyamatos fejlesztése elengedhetetlen követelmény ... Nem történhet meg az, hogy az állami bürokrácia fékezze a gazdasági növekedést." (Magyar Kormány, 2015)

Mint Budai is megállapítja, ,a közigazgatás jellegéből és funkcióiból fakadóan föként adat, információs és tudástárakkal foglalkozik ... célja, hogy minél több információt és minél több szolgáltatást online el lehessen érni." (Budai, 2009, p. 93, 47)

Jelen cikk szerzői egy olyan közszolgálati informatikai fejlesztés részesei voltak az év első felében, amelynek célja az volt, hogy egy olyan, minisztériumi szakmai müködtetésben lévő egységes rendszer rendszertervét készítsék el, amely magában foglalja az azt működtető szervezet honlapját, újratervezi két már meglévő személyügyi rendszer működését, valamint kialakít két újabb személyügyi alrendszert. 


\section{A tervezés szerepe a szoftverfejlesztésben}

Az egyre bonyolultabb elvárásoknak megfelelni képes összetett rendszereket, így az összetett információs rendszereket is, tervezni szükséges. A számítástechnika hőskorával ellentétben, amikor egy-egy program elkészítéséhez számos esetben egy fejlesztő is elegendő volt, ma már a fejlesztések számos, cégen belüli fejlesztő team együttmüködésében valósulnak meg. A csapatmunkában történő fejlesztésnek számos előnye van, amelyek közül a leglényegesebbek az alábbiak:

- az erőforrás igény jobban becsülhető,

- a kijelölt határidő könnyebben tartható,

- a teamek tagjai a saját szakterületüknek megfelelö részfeladatokkal foglalkozhatnak,

- a tesztelés teljeskörübbé válik,

- a program későbbi módosítása illetve bővítése könnyebben kivitelezhető.

Napjainkban a szoftverfejlesztés talán legnagyobb kihívása az egyre nagyobbá és bonyolultabbá váló rendszerek összetettségének kezelése. Ezért a szoftverfejlesztés technológiája törekszik a rendszerfejlesztés folyamatának racionalizálására, az egyes fejlesztési folyamatok keretek közé szorítására. Kialakultak különböző életciklus modellek, amelyek célja a fejlesztési folyamat modellezése az alábbi 4 szint mentén:

- Követelmények megfogalmazása - funkcionális specifikáció. E lépcsőben a megrendelő és a fejlesztő részletes helyzetfelmérést végez, melynek végén megfogalmazza azt, hogy a szoftvertermék kifejlesztésének mi a célja, mi a kifejlesztendő szoftvertermék feladata (illetve mi nem feladata), milyen sajátosságokkal kell, hogy rendelkezzen, milyen funkciók megvalósítására legyen képes.

- Rendszertervezés (design) - rendszerterv. Jellemzően a fejlesztő cég tervezéssel foglalkozó szakemberei a megrendelő szempontjait figyelembe véve megfogalmazzák, hogy a megrendelő által elképzelt rendszer milyen specifikációkkal rendelkezik, illetve kialakítják a rendszer átfogó architektúráját. A későbbi részletes rendszerterv alapjául szolgáló konceptuális illetve nagyvonalú rendszertervet a megrendelő szakemberei egyaránt elkészíthetik, ennek célja, hogy a fejlesztő számára iránymutatásul szolgáljon, illetve a szoftvertermék elkészültekor, a terv segítségével a megrendelő ellenőrizni tudja, hogy a fejlesztő a kívánt funkciókat tartalmazó rendszert fejlesztette-e ki.

- Kódolás, testreszabás és tesztelés. Ebben a szakaszban kerülnek kifejlesztésre a kifejlesztendő szoftvertermék különféle programegységei, történik meg ezek integrációja. Elkészül a szoftvertermék dokumentációja. A tesztelés célja annak megállapítása, hogy a rendszer egyes elemei összhangban vannak-e egymással (verifikáció), illetve, hogy megfelel-e a megrendelö által támasztott követelményeknek (validáció). A tesztelés után a szoftverrendszer átadható az ügyfélnek.

- Bevezetés. A szoftvertermék megrendelő általi átvétele és használatba vétele. (Ficsor Krizsán-Mileff, 2011)

Jelen cikkünkben a szoftverfejlesztés folyamatának rendszertervezési szakaszára koncentrálunk, mivel a szerzők a közszolgálati információs rendszer tervezésében, azon belül is a nagyvonalú rendszerterv elkészítésében vállaltak szerepet.

A bemutatott projekt a Közigazgatás- és Közszolgáltatás-fejlesztés Operatív Program (KÖFOP) keretein belül valósul meg. A program célja, hogy felhasználóbarát informatikai HR rendszerekkel stabil és biztonságos hátteret alakítson ki a rendszerek felhasználói számára, oly módon, hogy az igénybe vett szolgáltatások teljes körüen elektronikus formában intézhetők legyenek. Az alprojekt, melynek részesei voltunk, 2016 folyamán indult, s több hónapos egyeztetés után 2017 januárjában jutott el abba a fázisba, hogy a rendszertervezés folyamata 
megkezdődhetett. A mi munkánk ekkor vette kezdetét, a szerzők közül ketten informatikai munkatársként kerültek be a felelős minisztérium személyi állományába, míg harmadik szerzőtársunk kívülről, konzulensként segítette munkánkat. Feladatunk az volt, hogy a rendelkezésre álló dokumentumok (pl. korábbi rendszerleírások, felhasználói kézikönyvek, újonnan elkészített müszaki leírások, továbbá indikatív árajánlat bekérő), illetve a minisztériumi kollégák bemutatói, valamint velük történő megbeszélések alapján elkészítsük a kialakítandó egységes rendszerre, illetve tartalmazott alrendszereire vonatkozó rendszertervet, amelynek alkalmasnak kellett lennie a következő céloknak megfelelni:

- a rendszerterv alapján a rendszer fejlesztésére vonatkozó közbeszerzés kiírható legyen;

- a rendszerterv legyen képes segíteni a fejlesztés lehetőségét a közbeszerzés keretében megszerző vállalkozót a rendszer sikeres kifejlesztésében;

- a rendszerterv alapján a megbízó minisztérium képes legyen a fejlesztés sikerességét megállapítani.

Munkánk tehát az előzőekben bemutatott 4 pont közül a másodikra koncentrálódott, bár a követelmények megfogalmazásának is aktív részeseivé váltunk, azáltal, hogy újabb, fejlesztői szempontból fontos elemekre is felhívtuk a figyelmet, melyek később követelményekként a rendszerterv részeivé váltak.

A tervezés lényege, hogy a követelményeknek megfelelő rendszer a lehető leghatékonyabban megvalósítható legyen. A teljes tervezési folyamatot Ficsor - Krizsán Mileff (2011) négy magas szintü tervezési folyamatra bontja, az alábbiak szerint:

- A rendszer üzleti használatának felmérése, ami magában foglalja az elvárások megismerését, illetve egyes pontjainak tisztázását.

- A követelmények feltárása és elemzése, a különböző események lekövetésével, a megrendelővel történő folyamatos egyeztetésekkel.

- A követelmények átalakítása valamilyen szabványos formátumra. A kialakítandó rendszer adatszerkezeti alapmodelljének, logikai adatcsoportjainak kialakítása. A rendszer által megvalósítani kívánt folyamatok leírása.

- Ellenőrzés, hogy a követelmények a megrendelő által kívánt rendszert definiálják-e. Ez a lépés a megrendelő munkatársaival történő egyeztetéssel és végül a rendszerterv megrendelö általi átvételével valósulhat meg.

A rendszer üzleti használatának felmérését a kollégák nagyrészt elvégezték, így a mi feladatunk az elvárások megismerése, egyes pontjainak tisztázása volt.

A követelmények feltárásakor elsőként a jelenleg müködő rendszereket tekintettük át. Igyekeztünk ezek müködését a kollégák segítségével megismerni, a különböző eseményeket bennük lekövetni. Ezt követte mind az újratervezett, mind a kialakítandó új rendszerek esetében a követelmények a meglévő dokumentáción alapuló, a kollégákkal történő folyamatos egyeztetésekkel támogatott megismerése.

A követelmények szabványos formátumra történő alakításakor a folyamat orientáltságot és az adat-központúságot helyeztük a középpontba. A rendszer müködését fizikai szinten a rendszer, valamint az egyes alrendszerek adatszerkezeti alapmodelljének, logikai adatcsoportjainak, valamint az ezekhez tartozó javasolt adatkörök, továbbá az ügymeneti adatok meghatározásával írtuk le.

Az alrendszerek logikai bemutatásakor a folyamatok leírására koncentráltunk. Ennek során a jól ismert UML ábrák közül a használati eset és az aktivitás diagramokat használtuk, míg a fontosabb folyamatok megértését szekvencia diagramok készítésével igyekeztünk elősegíteni. Nagy hangsúlyt fektettünk a jogosultságok bemutatására is, ezt alrendszerenként egy-egy jogosultsági mátrixban mutattuk be. 
Annak az ellenőrzése, hogy a követelmények a megrendelő által kívánt rendszert definiáljáke, a rendszerterv pontonkénti, a megrendelővel történő részletes átnézésével, a későbbi fizikai múködtetést végző Nemzeti Infokommunikációs Szolgáltató Zrt. (NISZ) munkatársaival történő egyeztetéssel és végül a rendszerterv megrendelő általi átvételével valósult meg.

A tervezési folyamat végterméke a rendszerterv. A rendszerterv a teljes tervezési folyamatot hivatott leírni, az a tervezési dokumentum, mely alapján a programozók a kijelölt szoftverterméket elkészítik.

\section{A rendszerterv}

A rendszerterv egy írásban rögzített specifikáció, amely nem csupán a rendszert magát írja le, hanem azt is, hogy azt miért (rendszer célja), hogyan (terv), mikor (időpont), és miből (erőforrások) akarjuk létrehozni (Kusper - Radványi, 2011, p. 147). Részletezettség szempontjából a rendszerterv 3 fö fajtáját különböztethetjük meg, beszélhetünk konceptuális, nagyvonalú és részletes rendszertervröl. A konceptuális rendszerterv röviden írja le, mit és miért akarunk a jövőben létrehozni. A nagyvonalú rendszerterv ezen felül leírja, hogy milyen lépéseket kell véghezvinni és az egyes lépésekhez milyen erőforrásokra van szükségünk. A részletes rendszerterv az előzőeken felül megadja a lépések idejét, ezzel egy olyan szintre eljutva, hogy a rendszerterv a tervező részvétele nélkül is végrehajtható legyen (Kusper Radványi, 2011).

A rendszerterv megadja, hogy a megvalósítani kívánt szoftvernek mit kell tartalmaznia, milyen követelményeknek kell megfelelnie. A megvalósítandó funkciók alapján megkülönböztetünk funkcionális, nem funkcionális és szakterületi követelményeket. A funkcionális követelmények leírják, hogy a rendszernek milyen funkciókkal kell rendelkezni, hogyan kell a későbbiekben müködnie. A nemfunkcionális követelmények nem közvetlenül a rendszer által biztosított specifikus funkciókkal foglalkoznak, hanem inkább a rendszer egészére vonatkozó rendszertulajdonságokra koncentrálnak. A szakterületi követelmények a rendszer alkalmazási szakterületéről származnak és e szakterület jellegzetességeit és megszorításait tükrözik (Ficsor - Krizsán - Mileff, 2011, p. 28).

Az általunk készített nagyvonalú rendszerterv mindhárom előbb említett követelményfajtába tartozó elemeket felvonultat. A funkcionális és nemfunkcionális követelményeket a megrendelő szervezet elképzelései szerint magunk állítottuk össze, míg a szakterületi követelmények összeállítása az egyes területekért felelős kollégák feladata volt. A funkcionális követelményeket elsősorban a folyamatok UML viselkedési diagramok készítésével és az egyes funkciók szöveges leírásával mutattuk be, a nemfunkcionális követelmények azonban elsősorban rövid szövegközi utalások formájában jelentek meg a rendszertervben.

A követelmények leírásán felül a rendszerterv - az előzőekben kifejtett részletezettsége szerint - a rendszer következő szempontok bemutatását tartalmazhatja:

- az implementálandó szoftver struktúrája,

- az adatok szervezése és áramlása a rendszerben,

- a rendszerkomponensek közötti interfészek tisztázása,

- a használt algoritmusok leírása,

- a felhasználói felületek tervezési elvei (Ficsor - Krizsán - Mileff, 2011).

A megvalósítandó szoftvertermék struktúráját célszerü kisebb egységekre, a szolgáltatásokat megvalósító komponensekre bontani. Az alrendszerek önálló rendszerek, melyek müködése nem függ más rendszerektöl, míg a modulok olyan rendszerkomponensek, melyek más modulok számára biztosítanak szolgáltatásokat. Ezek az alrendszerek, illetve modulok méretük okán a fejlesztői teamek számára jobban kezelhetők. Ezt a felbontást architekturális illetve 
moduláris felbontásnak nevezzük. Meg kell tervezni ezen komponensek egymás felé mutatott interfészeit is.

A tervezett rendszer architekturális felbontását a korábban elkészült fejlesztési dokumentációk, így a müszaki leírások, illetve a rendszer tervezésére vonatkozó indikatív árajánlat bekérő nagyrészt meghatározta. A rendszer 4 önállóan is müködni képes alrendszert kell, hogy tartalmazzon, illetve a fejlesztés során el kell készíteni a rendszert müködtető szervezet honlapját is.

A moduláris felbontás részben szintén adott volt, a két már müködő, de újratervezendő és fejlesztendő alrendszer 3 illetve 2 modult tartalmazott, mely szerkezetet a megbízó meg kívánt tartani. A tervezés során merült fel az igény, hogy az első, újratervezendő alrendszer szerkezetébe egy újabb modul kerüljön be. Mivel az általunk készített tervdokumentum szerint a 4 alrendszer kiszolgálását egy közös adatbázis végezné, indokoltnak tünt, hogy a rendszer a 4 alrendszer mellett egy különálló adminisztrációs modult is tartalmazzon, amely az alrendszerek mindegyikét kiszolgálni hivatott. (1. ábra)

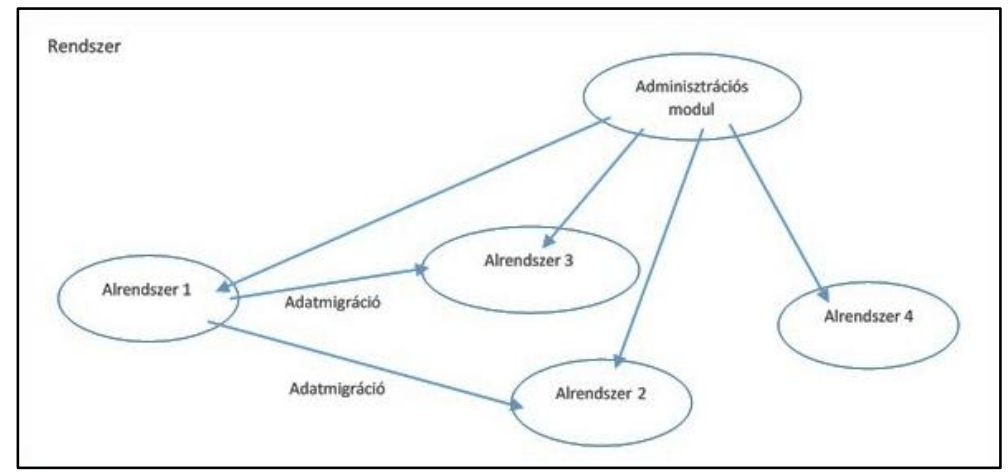

1. ábra. A rendszer és alrendszereinek, moduljainak kapcsolata (saját szerkesztés)

Az egyes alrendszerek és modulok folyamatainak leírására a szabványosított grafikus jelölésrendszerrel rendelkező UML (Unified Modeling Language) - egységes modellező nyelvet használhatjuk. Az UML diagramokból áll, melyek a modell egészének vagy részének egy adott nézőpontját fejtik ki. Az egyes diagramok konkrét rálátást biztosítanak a modellezett rendszer egy-egy kisebb szeletére. A diagramok két nagy csoportja a szerkezeti (statikus) és a viselkedési (dinamikus) diagramok. (Szabolcsi, 2012)

A tervezés során a szerkezeti diagramok készítésébe nem bocsátkoztunk bele, úgy gondoltuk, hogy ez a későbbiekben a fejlesztést elnyerő vállalkozás illetékességi köre. Feladatukat megkönnyítendő a rendszer elvárt viselkedésére vonatkozóan számos viselkedési diagramot illesztettünk a rendszertervbe szöveges magyarázattal kiegészítve, arra törekedve, hogy a majdani fejlesztők feladatát megkönnyítsük, érthetővé tegyük számukra a megbízó által a rendszertől elvárt viselkedést.

A tervezés során felmértük, hogy kik azok az aktorok, akik a rendszert, illetve annak alrendszereit használni fogják (2. ábra). Ezt követően alrendszerenként jogosultsági szinteket határoztunk meg, a jogosultsági szinthez tartozó felhasználók által elérhető funkciók meghatározásával. Ezt követően alrendszerenként egy-egy használati eset diagramon mutattuk be az alrendszert használó aktorokat és általuk elérhető funkciókat, illetve egy jogosultsági mátrixban is ábrázoltuk azok kapcsolatát.

A használati eset diagram a rendszer és környezete kapcsolatát mutatja be, egy olyan jelölés rendszert biztosít, amelyet a megrendelő szakemberei és a programozók is könnyen megértenek, ami segíti a félreértések elkerülését a két fél közt.” (Kusper - Radványi, 2011) 


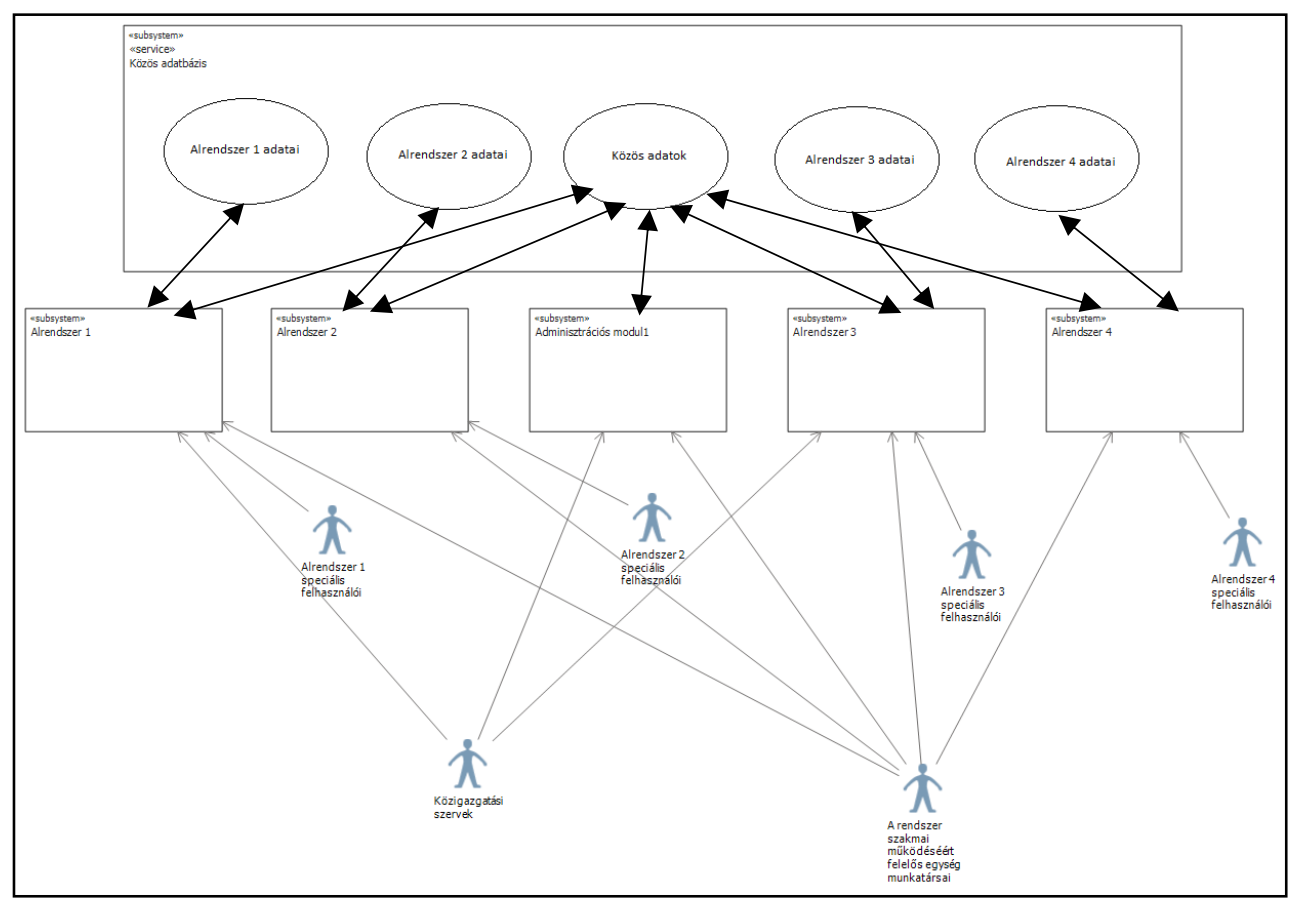

2. ábra: Az adatbázis, az alrendszerek illetve a felhasználók kapcsolatai (saját szerkesztés)

Az újratervezett két, a másik két alrendszernél összetettebb alrendszer esetében az alájuk tartozó modulok bonyolultsága indokolta, hogy a főbb folyamatokat aktivitás- és szekvenciadiagramokon is ábrázoljuk. Az aktivitásdiagram a rendszeren belüli tevékenységek leírására szolgál, így az egyes felhasználók számára a rendszer által nyújtott szolgáltatások bemutatására használtuk. A szekvenciadiagram az objektumok közötti üzenetváltásokat mutatja be, így alkalmasnak bizonyult az egyes modulokban lezajló folyamatok ábrázolására.

A rendszer müködését fizikai szinten a rendszer adatszerkezeti alapmodelljének, logikai adatcsoportjainak, valamint az ezekhez tartozó javasolt adatkörök, továbbá az ügymeneti adatok meghatározásával írhatjuk le.

A rendszer adatszerkezeti alapmodelljének tervezésekor elsőként a rendszerben megjelenő adatokat tekintettük át. Összegyüjtöttük azokat a logikai adatcsoportokat és az ezekhez tartozó javasolt adatköröket, amelyek a rendszerhez tartozó adatbázist fogják alkotni. A következő adatcsoportokat különítettük el: szervezeti adatok, személyi adatok, jogosultságok, ügymenetek adatai, kódtáblák, tevékenység napló adatai. Az adatbázisra vonatkozó tervet ez alapján készítettük el az EER modell szerint, mely az ER modell alapján az adatokat mint egyedeket, kapcsolatokat és attribútumokat írja le, kibővítve az osztály/alosztály kapcsolat és a típusöröklődés fogalmával.

Az adatbázisra vonatkozó terv a következő adatcsoportokat különíti el: szervezeti adatok, személyi adatok, jogosultságok, ügymenetek adatai, kódtáblák, tevékenység napló adatai.

$\mathrm{Az}$ adatbáziskezelő rendszerre vonatkozóan megkötéseket nem tettünk, mivel a közbeszerzési eljárásban nem adható meg konkrét utalás ezekre vonatkozóan, ugyanakkor néhány javaslattal éltünk. Ezek a következők voltak:

- a felhasználói adatok és a tevékenységnapló szétválasztása javasolt,

- az adatok tárolásának és elérésének gyorsabbá tétele érdekében indokolt legalább 2 adatbázis szerver üzembe helyezése,

- az adatbázis-kezelő rendszer kiválasztásakor figyelemmel kell lenni az összetett adatszerkezetre és a várható nagymennyiségü adattárolási igényre is. 
A rendszerterv elkészültét követően, az abban foglalt irányelveket követve kezdődhet el a fejlesztési folyamat, amelynek során a rendszertervben körülírt követelményeknek megfelelö szoftvertermék megvalósítása a cél. Ugyanakkor a tervezési folyamatot sem tekinthetjük befejezettnek. Ma már a szoftverek fejlesztése nem elsősorban a vízesés modell szerint zajlik, mely esetében a rendszertervezés fázisát követi annak megvalósítása, hanem egyéb módszerek is előtérbe kerültek, melyek a tervezési folyamat fázisainak iteratív végrehajtását részesítik előnyben. Ezáltal a rendszertervezés fázisa, az nagyvonalú rendszerterv elkészítését követően a megvalósítás, és tesztelés fázisával közösen fut tovább, és azokkal közösen szolgáltatja a szoftverfejlesztési folyamat eredményét, az elkészült szoftvert.

\section{Összefoglalás}

Cikkünkben ismertettük az információs rendszerek tervezésének jelentőségét a szoftverfejlesztés folyamatában. Egy gyakorlati példán keresztül bemutattuk, hogy az egyes tervezési szempontok miként valósultak meg egy közszolgálati információs rendszer tervezésekor, melyben a szerzők is szerepet vállaltak. A rendszer, az alrendszerei illetve egyes elemeinek bemutatásakor azok nevesítésére nem kerülhetett sor, hiszen egy olyan rendszerröl van szó, amely jelen pillanatban is fejlesztés alatt áll, illetve a szerzők által aláírt munkaszerződések titoktartási kötelezettséget írnak elő. Ezzel együtt is úgy gondoljuk, hogy a tervezési szempontok megvalósulása a bemutatott rendszertervben jól nyomon követhetö, későbbi tervezési feladatoknál mintául szolgálhat.

\section{Irodalomjegyzék}

Budai B. B. (2009). E-közigazgatás axiomatikus megközelitésben. PhD doktori értekezés Pécsi Tudományegyetem Ảllam- és Jogtudományi Kar Doktori Iskola, Pécs, 2009.

Ficsor L. - Krizsán Z. - Mileff P. (2011). Szoftverfejlesztés. Miskolci Egyetem, Miskolc, 2011, 167 p.

Kusper G. - Radványi T. (2011). Programozás technika. Eszterházy Károly Főiskola, Eger, 2011, 211 p.

Magyar Kormány (2015). Közigazgatás- és Közszolgáltatás-fejlesztési Stratégia 2014-2020. Budapest, $2015,101 \mathrm{p}$.

Raffai M. (2003). Információrendszerek fejlesztése és menedzselése - Novadat Bt., Győr, 2003, 998 p. Szabolcsi J. (2012). Szoftvertechnológia. 98 p.

Szenteleki K. - Rózsa T. (2007). Információs rendszerek. DE AMTC AVK 2007 Debrecen, 2007. 214 p. 